\title{
Effect of exogenous phytase on feed inositol phosphate hydrolysis in an in vitro rumen fluid buffer system
}

\author{
D. N. Brask-Pedersen, ${ }^{\star}$ L. V. Glitsø, $†$ L. K. Skov, $\nmid$ P. Lund, ${ }^{*}$ and J. Sehested ${ }^{\star 1}$ \\ *Department of Animal Health and Bioscience, Faculty of Agricultural Sciences, Aarhus University, PO Box 50, 8830 Tjele, Denmark \\ †R\&D, Novozymes A/S, 2880 Bagsvaerd, Denmark
}

\begin{abstract}
Three in vitro experiments using a rumen fluid buffer system were performed to investigate the effect of addition of 4 experimental phytases (Phy1, Phy2, Phy3, and Phy4) compared with no addition of phytase on feed inositol phosphate hydrolysis in wheat and rapeseed cake to determine which of the 4 phytases was most suitable under rumen-like conditions. The feedstuffs were incubated with a mixture of physiological buffer, ruminal fluid, and exogenous phytase at $\mathrm{pH} 6.2$, after which the samples were incubated for different periods. Incubations were stopped using $\mathrm{HCl}$, and the samples were analyzed for inositol phosphates via high performance ion chromatography. Addition of phytase (Phy1) resulted in enhanced degradation of myo-inositol hexakisphosphate $\left(\mathrm{InsP}_{6}\right)$ in rapeseed cake, whereas addition of exogenous phytase did not improve the degradation of $\mathrm{InsP}_{6}$ in wheat. Only rapeseed cake was therefore used subsequently. All 4 phytases increased degradation of $\mathrm{InsP}_{6}$ in rapeseed cake in the in vitro system, and degradability of $\operatorname{InsP}_{6}$ increased with higher incubation time and higher phytase dosages, independent of phytase. Addition of 2 units of phytase per gram of substrate of the phytases Phy1, Phy2, Phy3, and Phy4 led to an undegraded $\operatorname{InsP}_{6}$ content of 56, 49, 70, and $18 \%$, respectively, when incubated with rapeseed cake for $6 \mathrm{~h}$, indicating that Phy2 and Phy 4 were the most effective phytases. However, Phy2 had a higher specific activity than Phy 4 , as $60 \%$ of the original $\mathrm{InsP}_{6}$ content was remaining after $3 \mathrm{~h}$ when $5 \mathrm{mg}$ of enzyme protein per gram of substrate of Phy2 was added to rapeseed cake, whereas $150 \mathrm{mg}$ of enzyme protein per gram of substrate of Phy 4 was necessary to achieve a similar result. Therefore, Phy2 appeared to be most applicable under rumen-like conditions.
\end{abstract}

Key words: phosphorus, inositol phosphate, phytase, rumen

\footnotetext{
Received June 4, 2010.

Accepted November 1, 2010.

${ }^{1}$ Corresponding author: Jakob.Sehested@agrsci.dk
}

\section{INTRODUCTION}

Phosphorus $(\mathrm{P})$ is an essential mineral nutrient for cattle, but environmental concerns are often linked to P (Sharpley and Winthers, 1994). Phosphorus intake and excretion in cattle are tightly linked (Morse et al., 1992a; Wu et al., 2000; Dou et al., 2003), and therefore even small improvements in the availability of feed $\mathrm{P}$ will improve whole-farm $\mathrm{P}$ balance and decrease potential P runoff from farms (Knowlton et al., 2004).

Phytate (myo-inositol hexakisphosphate, $\mathbf{I n s} \mathbf{P}_{\mathbf{6}}$ ) is the main storage form of $\mathrm{P}$ in cereals, legumes, and oilseeds (Nelson et al., 1968; Viveros et al., 2000), and about 60 to $80 \%$ of total $\mathrm{P}$ in cereals is found as $\operatorname{InsP}_{6}$, whereas about 35 to $50 \%$ of total $\mathrm{P}$ in by-products such as soybean meal and rapeseed cake is found as $\operatorname{InsP}_{6}$ (Eeckhout and De Paepe, 1994; Viveros et al., 2000). Roughages have a much lower content of $\mathrm{InsP}_{6}$, and only traces have been found in alfalfa and different grasses (Nelson et al., 1976), as most roughage consists of stems and leaves. Phytase catalyzes the hydrolysis of $\operatorname{InsP}_{6}$, producing myo-inositol pentakis-, tetrakis-, tris-, bis-, and monophosphates (InsP $\mathbf{P}_{5}$ to $\mathbf{I n s} \mathbf{P}_{1}$, respectively). Inorganic phosphate is released during the hydrolysis of inositol phosphate (Irving, 1980; Wodzinski and Ullah, 1996). Phytases can be categorized into 3 major classes: (1) histidine acid phosphatases, (2) $\beta$-propeller phytases, and (3) purple acid phosphatases (Mullaney and Ullah, 2003). The protein tyrosine phosphatase-like phytases found in bacteria (e.g., Selenomonas ruminantium) in the rumen constitute a fourth class of phytases (Nakashima et al. 2007).

Until very recently inositol phosphate was considered to be totally available to ruminants because of the above-mentioned phytase activity in the rumen (Clark et al., 1986; Morse et al., 1992b). However, studies have indicated that degradability of $\operatorname{InsP}_{6}$ in the rumen can be negatively affected by processing of feedstuffs by heat or formaldehyde treatment (Konishi et al., 1999; Park et al., 1999; Bravo et al., 2000). Other studies have shown that the rumen degradation of $\mathrm{InsP}_{6}$ is not complete (Kincaid et al., 2005; Sehested and Lund, 2007), and a recent experiment showed that the mi- 
crobial phytase activity in the rumen of lactating cows was limiting for degradation of feed inositol phosphate (Sehested and Lund, 2007). The experiment showed that the ruminal degradation of inositol phosphate was increased by supplementation of exogenous phytase. This agrees with the findings of Knowlton et al. (2007), who found that exogenous phytase reduced $\mathrm{P}$ excretion in dairy cows.

Exogenous phytase is extensively used as a feed additive for monogastric animals (Poulsen et al., 2007). The efficiency of phytase depends on $\mathrm{pH}$ in the digestive tract, among other factors, and because monogastric animals and cattle have different $\mathrm{pH}$ in the digestive tract, the types of phytase used as feed additive in monogastric animals may not necessarily be the most effective phytases in cattle. Different phytases may vary in their effect on hydrolysis of inositol phosphate under rumen-like conditions.

The aim of the present experiment was to investigate the effect of 4 different experimental phytases on in vitro ruminal degradation of inositol phosphate of feedstuffs.

\section{MATERIALS AND METHODS}

Feed type, incubation time, and concentration of phytase were used to evaluate 4 phytases, to determine which of the 4 phytases was most efficient under rumenlike conditions.

\section{Phytases}

The 4 experimental phytases (Phy 1 to Phy 4 ) used were supplied by Novozymes A/S (Bagsvaerd, Denmark). Three of the phytases (Phy1, Phy2, and Phy3) were microbial histidine acid phosphatase phytases, and Phy 4 was a $\beta$-propeller phytase. The activity of phytase is expressed in 2 ways: (1) phytase units (FTU) or (2) specific activity (FTU per amount of enzyme protein). One FTU is the amount of enzyme that liberates 1 $\mu \mathrm{mol}$ of inorganic phosphate per minute from a 0.0051 $M$ Na-phytate solution at $\mathrm{pH} 5.5$ and $37^{\circ} \mathrm{C}$ (Engelen et al., 1994). Although the specific activities of Phy1, Phy2, and Phy3 were comparable, the specific activity of Phy 4 was approximately 100-fold lower.

Phytase activity was measured at $37^{\circ} \mathrm{C}$ in the $\mathrm{pH}$ range of 2.0 to 7.5 . A buffer cocktail ( $50 \mathrm{~m} M$ glycine, $50 \mathrm{~m} M$ acetic acid, and $50 \mathrm{~m} M$ Bis-Tris), with $\mathrm{pH}$ adjusted to the appropriate value with $4 \mathrm{M} \mathrm{HCl}$ or $4 M$ $\mathrm{NaOH}$, was used for all $\mathrm{pH}$ values. In brief, $75 \mu \mathrm{L}$ of phytase-containing solution was mixed with $75 \mu \mathrm{L}$ of substrate $[100 \mathrm{mg}$ of Na-phytate from rice (cat. no. P0109, Sigma-Aldrich, St. Louis, MO) in $10 \mathrm{~mL}$ of buffer]. Samples were incubated with shaking in an Eppen-
Table 1. Content of DM, total inositol phosphate P (InsP-P), and myo-inositol hexakisphosphate $\mathrm{P}\left(\mathrm{InsP}_{6}-\mathrm{P}\right)$ as well as phytase activity in the wheat and rapeseed cake used in the present experiment

\begin{tabular}{lcc}
\hline Item & Wheat & $\begin{array}{c}\text { Rapeseed } \\
\text { cake }\end{array}$ \\
\hline $\mathrm{DM}(\%)$ & 90.4 & 91.3 \\
InsP-P (mg/g of DM) & 2.7 & 8.3 \\
InsP $_{6}-\mathrm{P}(\mathrm{mg} / \mathrm{g}$ of DM) & 2.4 & 7.3 \\
${\text { Phytase (FTU/g of feed })^{1}}^{1}$ & 403 & 0 \\
\hline
\end{tabular}

${ }^{1}$ One FTU is the amount of enzyme that liberates $1 \mu \mathrm{mol}$ of inorganic phosphate per min from $0.0051 \mathrm{M}$ Na-phytate solution at $\mathrm{pH} 5.5$ and $37^{\circ} \mathrm{C}$ (Engelen et al., 1994).

dorf thermomixer for $15 \mathrm{~min}$ at $37^{\circ} \mathrm{C}$. Subsequently, 75 $\mu \mathrm{L}$ of stop reagent [mix of $10 \mathrm{~mL}$ of molybdate solution (10\% wt/vol ammonium hepta-molybdate in $0.25 \%$ wt/vol ammonia solution), $10 \mathrm{~mL}$ of ammonium vanadate $(0.24 \%$ commercial product from Bie \& Berntsen, cat. no. LAB17650; Bie \& Berntsen, Herlev, Denmark), and $20 \mathrm{~mL}$ of $21.7 \%$ (wt/vol) nitric acid] was added to terminate the enzymatic reaction and to form a colored phosphovanadomolybdate complex. Absorbance at 405 $\mathrm{nm}$ was measured in a Molecular Devices (Berks., UK) micro-titer plate reader.

\section{Feedstuffs}

Wheat (not heat treated) and rapeseed cake $(13.6 \%$ fat) were used as examples of grain and protein feeds, respectively. Content of DM, total inositol phosphate $\mathrm{P}$, and $\mathrm{InsP}_{6} \mathrm{P}$, as well as endogenous phytase activity, in the 2 feedstuffs are presented in Table 1. The feed samples were ground through a 1-mm screen by using a hammer mill. Feedstuffs were extracted in aqueous solution and analyzed for phytase activity (FTU) according to Engelen et al. (1994).

\section{Experiment 1: Effect of Phytase Addition, Feedstuff, and Incubation Time}

The experiment was a $2 \times 2 \times 4$ factorial design with 2 feedstuffs (wheat or rapeseed cake) incubated with or without phytase (Phy1 at $2 \mathrm{FTU} / \mathrm{g}$ of feed). Four incubation times $(0,3,6$, and $24 \mathrm{~h})$ were evaluated and each combination was replicated 3 times.

\section{Experiment 2: Effect of Phytase and Phytase Concentration}

The experiment was a $5 \times 2 \times 3$ factorial design with 1 feedstuff (rapeseed cake) incubated without or with 1 of 4 experimental phytases (control, Phy1, Phy2, Phy3, or Phy 4 ) at 2 concentrations of each phytase (1 or 2 FTU/g of feed). Based on experiment 1, 3 incubation 
times $(0,3$, or $6 \mathrm{~h})$ were evaluated. Each combination was replicated 5 times.

\section{Experiment 3: Effect of Phytase Type and Enzyme Protein Amount}

The 2 best-performing phytases from experiment 2 were used in experiment 3 . The experiment was a $2 \times$ $4 \times 3$ factorial design with 1 feedstuff (rapeseed cake) incubated without or with 1 of 2 phytases (control, Phy2, or Phy4) at 4 amounts of enzyme protein $(5,25$, 50 , or $150 \mathrm{mg}$ of enzyme/g of feed). Three incubation times $(0,3$, or $6 \mathrm{~h})$ were evaluated. Each combination was replicated 5 times.

\section{In Vitro Incubation}

The in vitro incubation used was a modification of the 2-stage technique for the in vitro digestion of forage crops that, in the original version, determines the potential OM or DM digestibility of feedstuffs for cattle (Tilley and Terry, 1963). In this study, only stage 1 was followed. The feedstuff was incubated with a mixture of ruminal fluid and physiological buffer solution modified after Tilley and Terry (1963): Bis-Tris (0.036 $M$; Sigma-Aldrich B4429), $\mathrm{NaHCO}_{3}(0.12 M)$, $\mathrm{NaCl}(0.008 M), \mathrm{KCl}(0.008 M), \mathrm{MgCl}_{2}, 6 \mathrm{H}_{2} \mathrm{O}(0.0006$ $M)$, and $\mathrm{CaCl}_{2} \cdot 2 \mathrm{H}_{2} \mathrm{O}(0.0004 M)$. All chemicals were of analytical grade.

Ruminal fluid was collected from 3 rumen-cannulated heifers maintained on a diet based on hay $(66 \%)$ and concentrate (33\%; DM basis). The ruminal fluid was strained through 2 layers of cheese cloth into preheated thermos bottles and kept at 38 to $39^{\circ} \mathrm{C}$. The ruminal fluid was always collected immediately before use and the ruminal fluids from the 3 heifers were mixed in the proportion 1:1:1. The ruminal fluid was then mixed with a premade $\mathrm{CO}_{2}$-gassed physiological buffer solution in the proportion $1: 5$, and $\mathrm{pH}$ was kept at 6.2 at $40^{\circ} \mathrm{C}$ by addition of $2 \mathrm{M} \mathrm{HCl}$. The $\mathrm{pH}(6.2)$ was lower than that used by Tilley and Terry (1963; pH 6.7 to 6.9), because the original phosphate buffer was replaced with a BisTris buffer to avoid buffer $\mathrm{P}$ interference and to achieve a $\mathrm{pH}$ close to the ruminal $\mathrm{pH}$ found in production animals. Approximately $0.5 \mathrm{~g}$ of feed was placed in each tube and $50 \mathrm{~mL}$ of the mixture of ruminal fluid and buffer solution was added along with phytase.

Phytases dissolved in demineralized water were added to the tubes $(0.5 \mathrm{~mL}$ in experiment 1 and $1.0 \mathrm{~mL}$ in experiments 2 and 3). Corresponding amounts of water were added to the control tubes. To obtain anaerobe conditions the tubes were gassed with $\mathrm{CO}_{2}$, sealed with a rubber cork, and incubated in a water bath at $40^{\circ} \mathrm{C}$ for $0,3,6$, or $24 \mathrm{~h}$. During incubation, samples were gently shaken after 1.5, 4.5, and $7 \mathrm{~h}$. Inositol phosphates were extracted from the in vitro samples following a slight modification of the method by Carlsson et al. (2001). In brief, $6 \mathrm{~mL}$ of $2 \mathrm{M} \mathrm{HCl}$ was added to each sample (50.5 $\mathrm{mL}$ in experiment 1 or $51 \mathrm{~mL}$ in experiments 2 and 3 ) and the resulting samples were mixed (500 rpm) for 3 $\mathrm{h}$ at $22^{\circ} \mathrm{C}$ interrupted by a freezing step. Subsequently, the samples were centrifuged $\left(1,800 \times g, 4^{\circ} \mathrm{C}, 5 \mathrm{~min}\right)$ and the supernatants were recovered. The addition of 2 $M \mathrm{HCl}$ reduced $\mathrm{pH}$ to $<1$ and the extractant thus also served to inactivate the phytase.

\section{Inositol Phosphate Analysis}

Inositol phosphates were analyzed using a modification of the method by Skoglund et al. (1997) described in detail by Pontoppidan et al. (2007). Before analysis, $500 \mu \mathrm{L}$ of the extract supernatant was placed in ultracentrifugal filter devices (Microcon YM-30, Millipore, Billerica, MA) and filtered by centrifugation $(12,000$ $\left.\times g, 0^{\circ} \mathrm{C}, 30 \mathrm{~min}\right)$. The filtered sample supernatants were analyzed undiluted by high performance ion chromatography (Dionex Corp., Sunnyvale, CA), and inositol phosphates $\left(\mathrm{InsP}_{6}\right.$ to $\left.\mathrm{InsP}_{3}\right)$ were detected after postcolumn reaction with $0.1 \% \mathrm{Fe}\left(\mathrm{NO}_{3}\right)_{3} \cdot 9 \mathrm{H}_{2} \mathrm{O}$ in a 20 $\mathrm{mL} / \mathrm{L}$ solution of $\mathrm{HClO}_{4}$, by UV absorbance at $290 \mathrm{~nm}$. A reference sample for the identification of peaks was prepared by dissolving $0.5 \mathrm{~g}$ of phytic acid dodecasodium salt hydrate in $50 \mathrm{~mL}$ of $0.5 \mathrm{M} \mathrm{HCl}$. The solution was autoclaved for $1 \mathrm{~h}$ at $124^{\circ} \mathrm{C}$. Before analysis, the hydrolysate was diluted 3 times in water. Peaks were quantified according to an $\operatorname{InsP}_{6}$ standard curve (0.01 to $\left.1 \mathrm{mM} \mathrm{InsP}{ }_{6}\right)$. The reference and standard samples were not extracted, being readily soluble, and also not filtered, as the $30-\mathrm{kDa}$ membrane is not expected to retain any of the inositol phosphates. The detector response factors of the lower inositol phosphates are lower than that of $\operatorname{InsP}_{6}$ because the number of attached phosphate groups that act with $\mathrm{Fe}^{3+}$ to give a UV response is lower. Theoretically, the response of Ins $\mathrm{P}_{\mathrm{X}}$ should be $\mathrm{X} / 6$ of that of the response of $\operatorname{InsP}_{6}$ and a correction factor of $6 / \mathrm{X}$ should be used. This principle was confirmed experimentally by Skoglund et al. (1997). Therefore, the amounts of $\mathrm{InsP}_{3}, \mathrm{InsP}_{4}$, and $\mathrm{InsP}_{5}$ were estimated in the current study using the theoretical correction factors of $2(=6 / 3), 1.5(=6 / 4)$, and $1.2(=6 / 5)$.

\section{Statistical Analysis}

Experiment 1. Data for inositol phosphates were analyzed using PROC MIXED (version 9.2, SAS Institute Inc., Cary, NC) and the response variables were expressed by a linear model. The variables in the analy- 


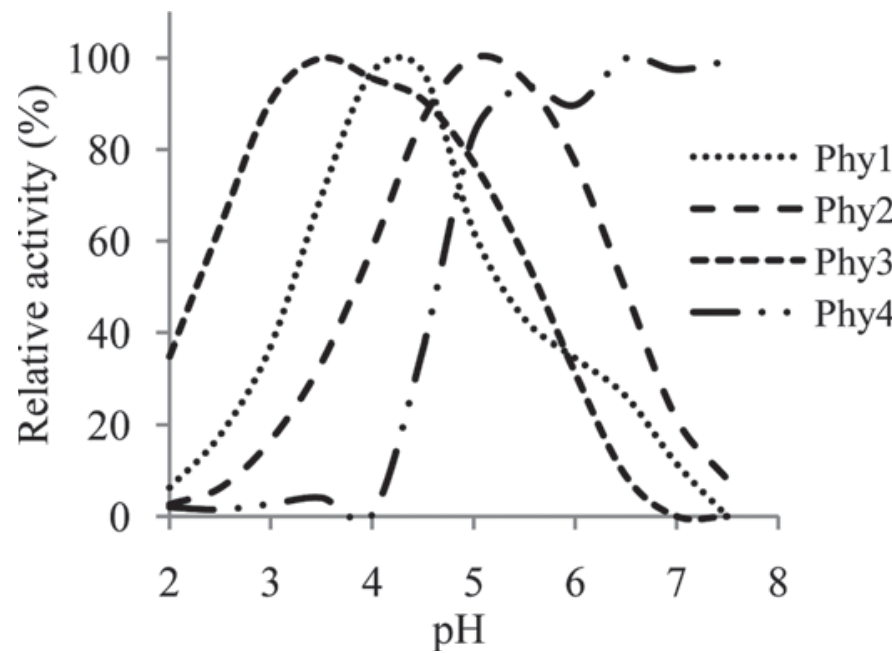

Figure 1. Relative activities as a function of $\mathrm{pH}$ for the 4 experimental phytases used in the present study. Activity at optimum $\mathrm{pH}$ $=100$.

ses were as follows: $\mathrm{Y}=$ dependent variable, $\mu=$ overall mean, $\mathrm{R}_{\mathrm{i}}=$ replicate number $(\mathrm{i}=1,2,3), \mathrm{F}_{\mathrm{j}}=$ feed $(\mathrm{j}$ $=$ wheat, rapeseed cake), $\mathrm{P}_{\mathrm{k}}=$ phytase addition $(\mathrm{k}=$ none, Phy 1$), \mathrm{T}_{1}=$ incubation time $(1=0,3,6,24)$, and $\varepsilon_{\mathrm{ijkl}}=$ residual error; interaction terms are represented as combinations of uppercase and subscript letters used to define the variables.

Effects of feed, phytase addition, and incubation time on the amount of $\operatorname{InsP}_{6}, \operatorname{InsP}_{5}, \operatorname{InsP}_{4}$, and $\mathrm{InsP}_{3}$ and percentage of undegraded $\mathrm{InsP}_{6}$ were evaluated with the model

$$
\begin{aligned}
\mathrm{Y}_{\mathrm{ijkl}}=\mu & +\mathrm{FPT}_{\mathrm{jkl}}+\mathrm{FP}_{\mathrm{jk}}+\mathrm{FT}_{\mathrm{jl}}+\mathrm{PT}_{\mathrm{kl}} \\
& +\mathrm{F}_{\mathrm{j}}+\mathrm{P}_{\mathrm{k}}+\mathrm{T}_{1}+\varepsilon_{\mathrm{ijkl}},
\end{aligned}
$$

with the term $\mathrm{R}_{\mathrm{i}}$ included in the random statement. All variables were treated as class variables. Significance of difference was declared when $P<0.05$; Tukey's test was used to separate the means when effect of treatment was declared significant. Data are presented as least squares of means and associated standard error of the means.

Experiments 2 and 3. The statistical model used in experiment 1 was also used to analyze data in experiment 2 and 3, except that the class variables were different and the number of replications was increased from 3 to 5 . The class variables used in experiment 2 were phytase (none, Phy1, Phy2, Phy3, and Phy4), concentration ( 1 and 2 FTU), and time $(0,3$, and 6 $\mathrm{h}$ ), and the class variables used in experiment 3 were phytase (none, Phy2, and Phy4), amount of enzyme protein $(5,25,50$, and $150 \mathrm{mg}$ of enzyme protein), and time $(0,3$, and $6 \mathrm{~h})$.

\section{RESULTS AND DISCUSSION}

\section{Phytases}

The relative activity of the 4 phytases (Phy1, Phy2, Phy3, and Phy4) as a function of $\mathrm{pH}$ is shown in Figure 1. The activity values for each $\mathrm{pH}$ are expressed as a percentage of the value at optimum. Phytase 3 had the lowest optimum $\mathrm{pH}$ whereas Phy4 had the highest optimum $\mathrm{pH}$ (3.5 vs. 6.5). Phytase 4 seemed to have a less well defined optimum $\mathrm{pH}$ than the other phytases. Phytase 1 and Phy 2 had more than $80 \%$ of their relative activity in a narrow $\mathrm{pH}$ range (3.7 to 4.8 and 4.2 to 6.0 , respectively), whereas Phy3 and Phy 4 had more than $80 \%$ of their relative activity in a broader $\mathrm{pH}$ range (2.7 to 5.0 , and 5.0 to 7.5 , respectively), indicating that Phy3 and Phy 4 were less sensitive for $\mathrm{pH}$ changes than were Phy1 and Phy2.

\section{Experiment 1}

The first experiment investigated the effect of adding phytase to 2 different feedstuffs and the effect of incubation time. The content of inositol phosphate $\mathrm{P}$ in wheat and rapeseed cake with or without phytase (Phy1) incubated at different times is shown in Figure 2. Rapeseed cake had a higher content of $\mathrm{InsP}_{6}$ compared with wheat, similar to the observation of Eeckhout and De Paepe (1994). A significant effect of the interaction between the factors feed type, incubation time, and phytase addition on the content of $\operatorname{InsP}_{6}(P<0.0001)$, $\operatorname{InsP}_{5}(P=0.0003), \operatorname{InsP}_{4}(P<0.0001)$, and $\operatorname{InsP}_{3}(P$ $<0.0001)$ was found. For both feedstuffs, degradation of $\mathrm{InsP}_{6}$ depended on incubation time. The longer the incubation times the more $\operatorname{InsP}_{6}$ was hydrolyzed; after $24 \mathrm{~h}$ of incubation, nearly all $\mathrm{InsP}_{6}$ was found to be hydrolyzed in both feedstuffs irrespective of phytase addition. However, after $6 \mathrm{~h}$ of incubation all $\mathrm{InsP}_{6}$ was already hydrolyzed in wheat independent of phytase addition, and degradation of inositol phosphate seemed to be much faster in wheat compared with rapeseed cake.

Addition of phytase increased the degradation of $\mathrm{InsP}_{6}$ in rapeseed cake irrespective of incubation time, whereas addition of phytase did not have any effect in wheat (Figure 3). The interaction between the factors feed type, incubation time, and phytase addition was found to affect the percentage of undegraded $\operatorname{InsP}_{6}$ $(P<0.001)$. The wheat used in the present study contained a much larger amount of natural phytase compared with rapeseed cake (403 vs. 0 FTU/g of feed), which agrees with other studies (Eeckhout and De Paepe, 1994), and this may explain why addition of an exogenous phytase had no additional effect on 


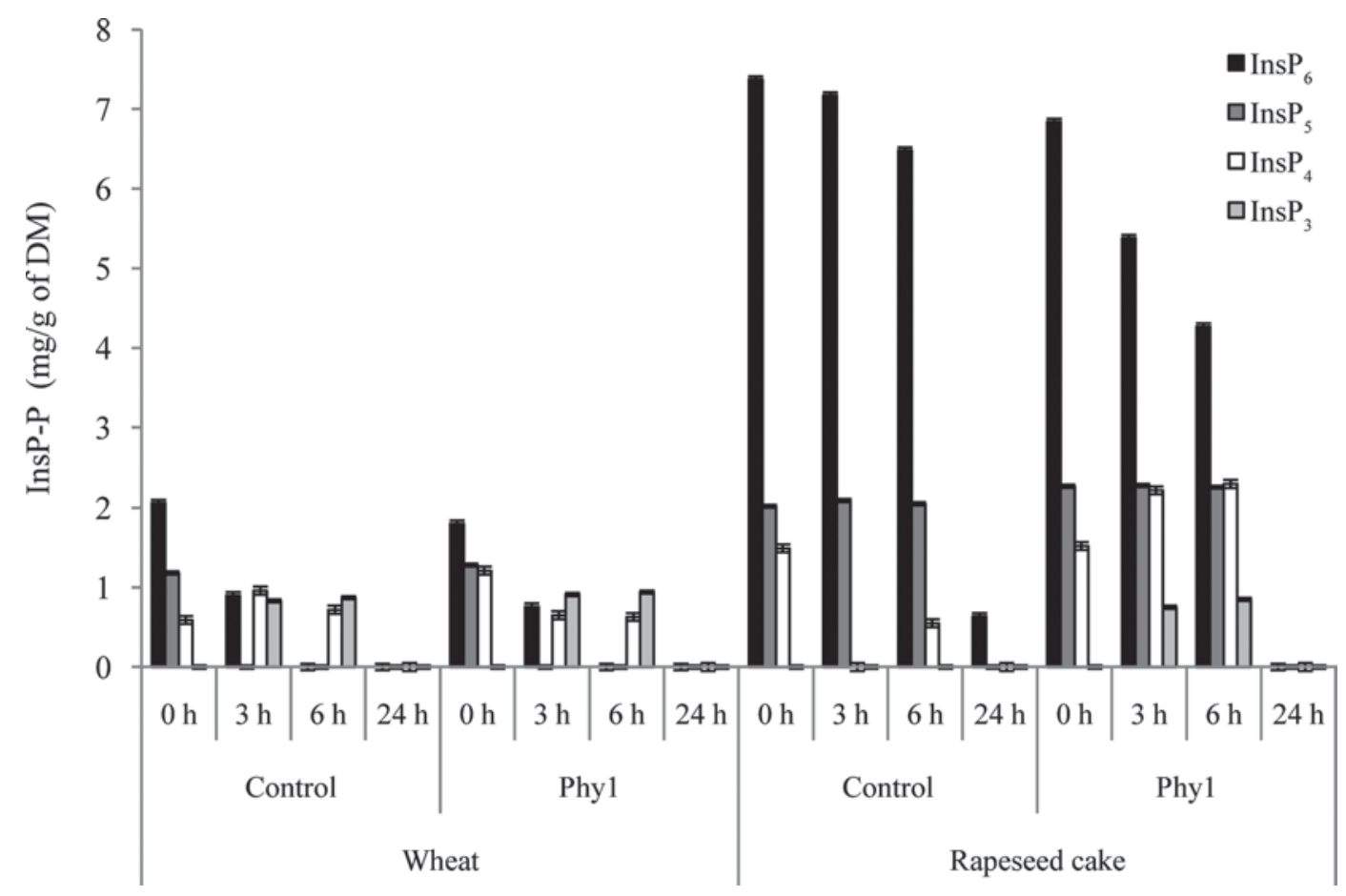

Figure 2. Undegraded inositol P (InsP-P) content shown for the individual inositol phosphates (myo-inositol hexakis-, pentakis-, tetrakis-, and trisphosphates, InsP $\mathrm{P}_{6}$ to $\mathrm{InsP}_{3}$ ) in wheat and rapeseed cake with or without phytase (Phy1) and incubation for $0,3,6$, or 24 h. Least squares means and SEM of 3 determinations are shown.

degradation of $\mathrm{InsP}_{6}$ in wheat. The rapid degradation of inositol phosphate in the wheat control sample compared with the rapeseed cake control sample can also be explained by the endogenous phytase activity in the wheat. Results indicate that a positive effect of adding exogenous phytase to a feed ration depends on which feedstuff the ration contains.

Degradation of inositol phosphates in the control samples could be caused by endogenous phytase activ-

(A)

Wheat

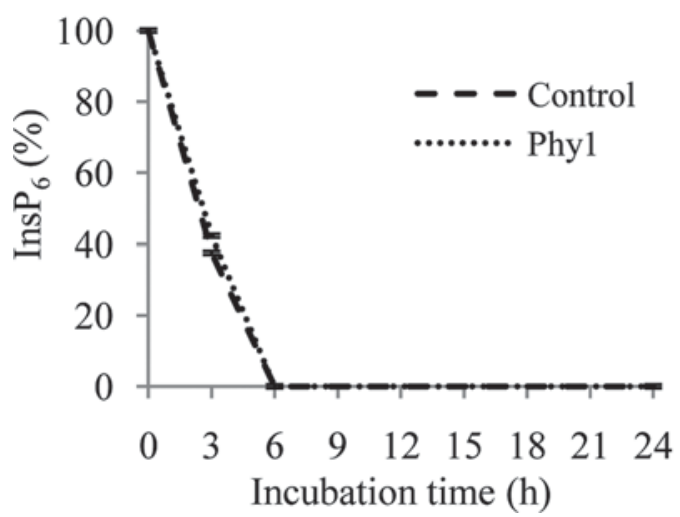

ity in feeds and the ruminal fluid. Only wheat contained phytase activity (Table 1), whereas inositol phosphate degradation in the rapeseed cake control samples was also significant. Therefore, endogenous phytase activity must also have been present in the ruminal fluid. $\mathrm{Ru}-$ minal phytase activity mainly originates from bacteria associated with the solid rumen fraction (Yanke et al., 1998). Ruminal fluid for this experiment was obtained by straining of ruminal samples through cheese cloth,

Figure 3. Percentage of undegraded myo-inositol hexakisphosphate $\left(\mathrm{InsP}_{6}\right)$ as a function of incubation time $(\mathrm{h})$ in wheat $(\mathrm{A})$ and rapeseed cake (B) with no phytase added (control) or with phytase (Phy1). Least squares means and SEM of 3 determinations are shown. 
(A) $1 \mathrm{FTU} / \mathrm{g}$ of feed

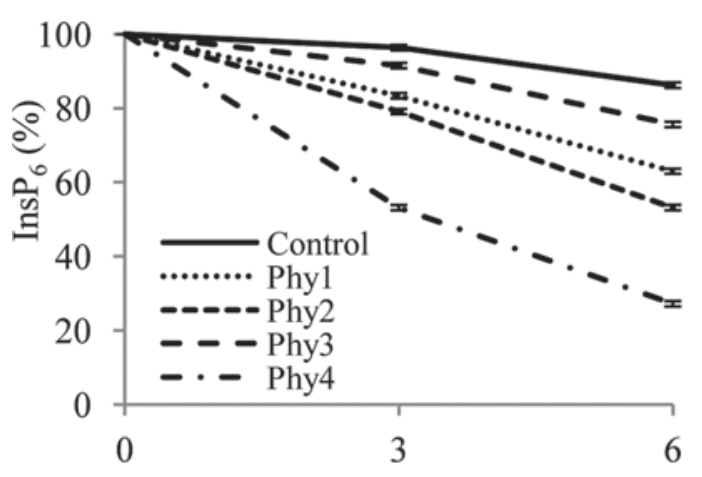

Incubation time (h)
(B) 2 FTU/g of feed

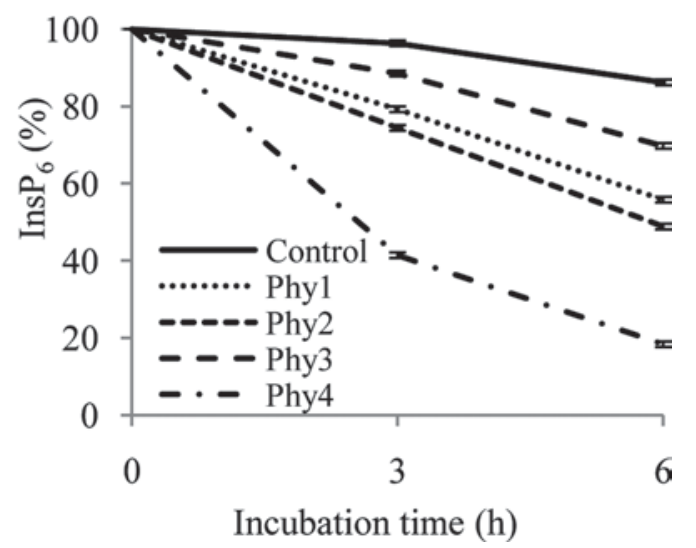

Figure 4. Percentage of undegraded myo-inositol hexakisphosphate ( $\operatorname{InsP}_{6}$ ) as a function of incubation time (h) in rapeseed cake with 1 FTU (phytase unit)/g of feed (A) or 2 FTU/g of feed (B) of 1 of 4 phytases (Phy1, Phy2, Phy3, Phy4) or none (control). Least squares means and SEM for 5 determinations are shown.

and it is not clear to what extent the observed inositol phosphate degradation in the rapeseed cake control samples reflect the in vivo condition.

It is clear from the present study (Figure 2) that degradation of $\mathrm{InsP}_{5}, \mathrm{InsP}_{4}$, and $\mathrm{InsP}_{3}$ starts before InsP $_{6}$ is depleted. The lower inositol phosphates seemed to accumulate when $\operatorname{InsP}_{6}$ was degraded (Figure 2), indicating competition for different inositol phosphate substrates by the phytase. Earlier studies have shown that $\mathrm{InsP}_{6}$ is the preferred substrate over $\mathrm{InsP}_{5}$ and $\mathrm{InsP}_{4}$ (Frias et al., 2003; Pontoppidan et al., 2007), and the present study indicates that degradation of $\mathrm{InsP}_{6}$ is the limiting step for complete degradation of inositol phosphate. It seems that when $\operatorname{InsP}_{6}$ was hydrolyzed, the rest of the inositol phosphates $\left(\mathrm{InsP}_{5}\right.$ to $\left.\mathrm{InsP}_{3}\right)$ followed soon after. Therefore, only data presenting the degradation of $\operatorname{InsP}_{6}$ will be shown for experiments 2 and 3 .

Based on the results from the first experiment, incubation times of 3 and $6 \mathrm{~h}$ were chosen for experiments 2 and 3 . Rapeseed cake was chosen to be the only feedstuff in the subsequent experiments because it contained a higher amount of $\operatorname{InsP}_{6}$ and because addition of phytase in non-heat-treated wheat did not have an additional effect on the degradability of $\operatorname{InsP}_{6}$.

\section{Experiment 2}

The second experiment compared 4 phytases and investigated the effect of the concentration (FTU/g of feed) of these phytases on degradation of $\mathrm{InsP}_{6}$ in rapeseed cake incubated in vitro. A significant interaction was observed between the factors incubation time, phytase addition, and phytase concentration on InsP $_{6}$ content $(P=0.027)$ and percentage of undegrad- ed $\operatorname{InsP}_{6}(P=0.027)$. The percentage of undegraded $\mathrm{InsP}_{6}$ as a function of incubation time in rapeseed cake when 1 of 4 phytases was added is presented in Figure 4. Results showed that higher incubation time leads to higher degradation of $\mathrm{InsP}_{6}$ in rapeseed cake, which confirms the findings in the first experiment. The addition and concentration of phytase also had an effect on the degradation of $\operatorname{InsP}_{6}$. The different phytases degraded rapeseed cake inositol phosphate to different extents. At similar phytase unit dosages (FTU/g of feed), Phy 4 most efficiently reduced the level of InsP $\mathrm{P}_{6}$ and Phy2 was found to be second best, and Phy3 was least efficient. Addition of $2 \mathrm{FTU} / \mathrm{g}$ of feed of the phytases Phy1, Phy2, Phy3, and Phy4 after $6 \mathrm{~h}$ of incubation led to an undegraded $\mathrm{InsP}_{6}$ content of $56,49,70$, and $18 \%$, respectively. These results are not surprising when the $\mathrm{pH}$ curves (Figure 1) for the 4 phytases are taken into consideration. Phytases Phy2 and Phy 4 had their optimum of activity at a higher $\mathrm{pH}$ than the other 2 phytases, and this higher $\mathrm{pH}$ is more similar to that found in the forestomachs of cattle. Using Ca-phytate and in vitro rumen fermentation, Raun et al. (1956) found that the optimal $\mathrm{pH}$ was 5.5 for phytate hydrolysis by ruminal microbes.

Moreover, addition of $2 \mathrm{FTU} / \mathrm{g}$ of feed led to greater hydrolysis of $\mathrm{InsP}_{6}$ compared with addition of $1 \mathrm{FTU} / \mathrm{g}$ feed, regardless of which phytase was added $(P<$ 0.0001). When $2 \mathrm{FTU} / \mathrm{g}$ of feed of each phytase was added, the $\mathrm{InsP}_{6}$ contents were 4.1, 3.6, 5.1, and 1.3 $\mathrm{mg} / \mathrm{g}$ of DM after $6 \mathrm{~h}$ of incubation compared with 4.6, $3.9,5.5$, and $2.0 \mathrm{mg} / \mathrm{g}$ of $\mathrm{DM}$ when $1 \mathrm{FTU} / \mathrm{g}$ of feed of the 4 phytases (Phy1, Phy2, Phy3, and Phy4) was added.

Phytases Phy2 and Phy4 were chosen to be further examined in a subsequent experiment because they 
(A) $5 \mathrm{mg}$ of enzyme protein/g of feed

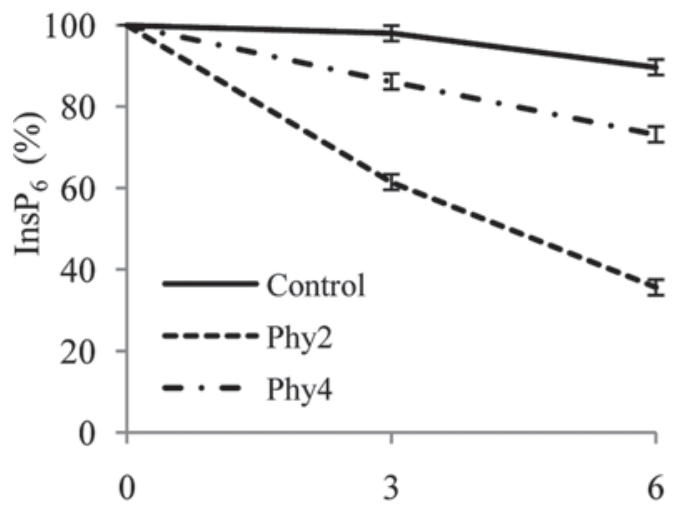

(C) $50 \mathrm{mg}$ of enzyme protein/g of feed

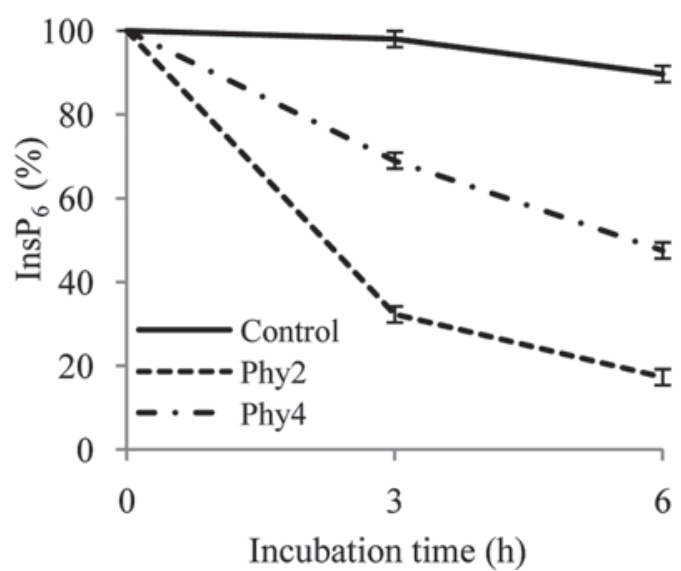

(B) $25 \mathrm{mg}$ of enzyme protein/g of feed

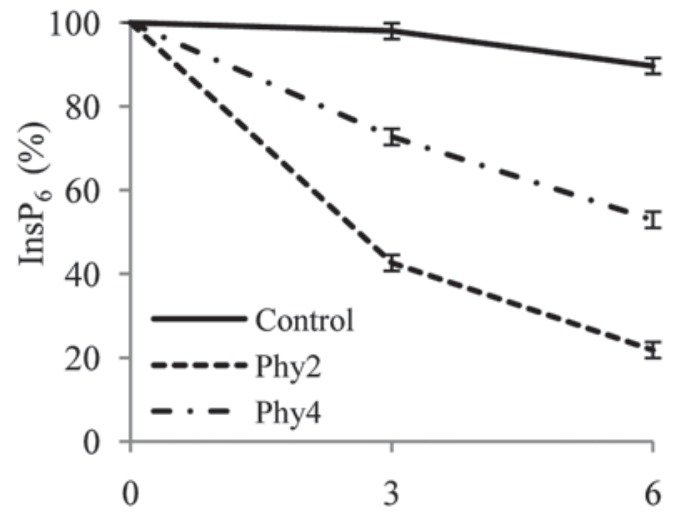

(D) $150 \mathrm{mg}$ of enzyme protein/g of feed

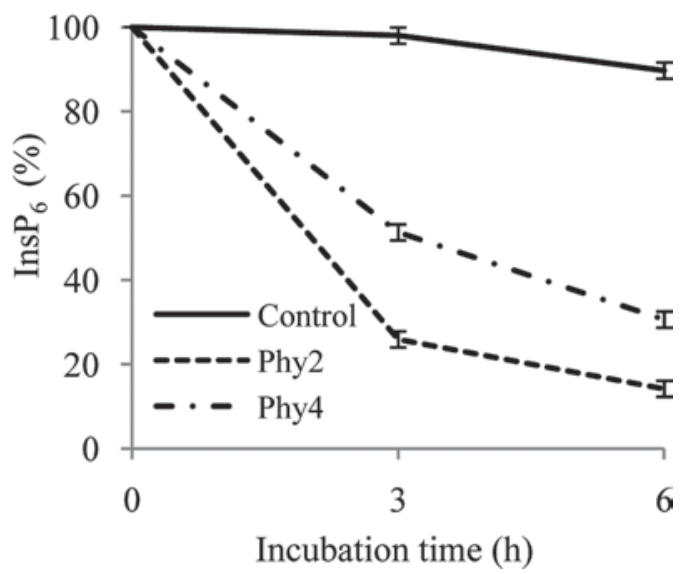

Figure 5. Percentage of undegraded myo-inositol hexakisphosphate $\left(\mathrm{InsP}_{6}\right)$ as a function of incubation time $(\mathrm{h})$ in rapeseed cake with no phytase, phytase 2 (Phy2), or phytase 4 (Phy4) at 1 of 4 concentrations: 5 (A), 25 (B), 50 (C), or 150 (D) mg of enzyme protein/g of feed. Least squares means and SEM for 5 determinations are shown.

were found to be most effective on degradation of $\operatorname{InsP}_{6}$ at given concentrations of phytase units.

\section{Experiment 3}

In experiment 2 , the phytases were compared at given concentrations of phytase units. In experiment 3 , Phy 2 and Phy 4 were dosed based on amount of enzyme protein per gram of feed, because the specific activity for the phytases was different (i.e., the amount of enzyme needed to obtain a phytase unit). The amount of enzyme protein varied $(5,25,50$, or $150 \mathrm{mg}$ of enzyme protein/g of feed), and Figure 5 shows undegraded $\mathrm{InsP}_{6}$ content when the 2 phytases were added. Significant effects of the interaction between the factors incubation time, amount of enzyme protein, and phytase on $\operatorname{InsP}_{6}$ content $(P=0.0041)$ and on percentage of undegraded $\operatorname{InsP}_{6}(P=0.0041)$ were found. Figure 5 confirms that hydrolysis of $\mathrm{InsP}_{6}$ depended on incubation time independently of choice of phytase (4.5 vs. 2.6 for Phy2 and 6.3 vs. 5.3 for Phy 4 at 3 and $6 \mathrm{~h}$ of incubation and concentration $5 \mathrm{mg}$ of enzyme protein/g of feed). Figure 5 also shows that a higher concentration of enzyme protein led to higher hydrolysis of $\mathrm{InsP}_{6}$ regardless of which of the 2 phytases was added to rapeseed cake. After $6 \mathrm{~h}$ of incubation, the undegraded $\mathrm{InsP}_{6}$ contents were 36 and $73 \%$ at $5 \mathrm{mg}$ of enzyme protein/g of feed versus 14 and $31 \%$ at $150 \mathrm{mg}$ of enzyme protein for Phy2 and Phy4, respectively. However, it seems that the marginal degradation of $\operatorname{Ins}_{6}$ declined when the concentration of enzyme increased. Figure 6 presents the percentage of undegraded $\mathrm{InsP}_{6}$ as a function of concentration ( $\mathrm{mg}$ of enzyme protein/g of feed), and it is clear that addition of higher concentrations of Phy2 did not lead to a higher degradation of $\operatorname{InsP}_{6}$ (17 vs. $14 \%$ after $6 \mathrm{~h}$ for the concentrations 50 and $150 \mathrm{mg}$ of enzyme protein).

Addition of Phy2 increased the degradation of $\operatorname{InsP}_{6}$ relative to addition of Phy 4 on a milligram to milligram basis (Figure 5). This trial clearly revealed that a higher 

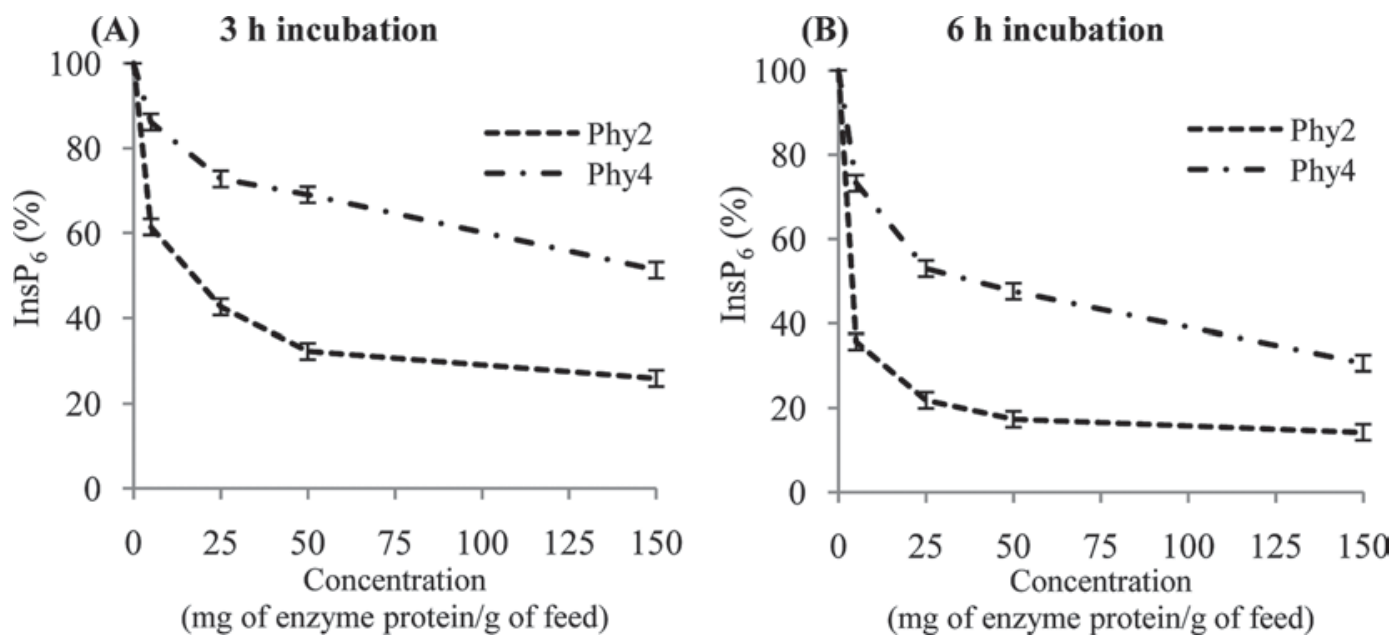

Figure 6. Percentage of undegraded myo-inositol hexakisphosphate $\left(\mathrm{InsP}_{6}\right)$ in rapeseed cake as a function of concentration (mg of enzyme protein/g of feed) of exogenous phytase (Phy2 or Phy4) at $3 \mathrm{~h}$ (A) or 6 h (B) of incubation. Least squares means and SEM for 5 determinations are shown.

amount of Phy4 enzyme protein is necessary to obtain the same effect as Phy2. Figure 5 shows that approximately $60 \%$ of the original $\operatorname{InsP}_{6}$ was left after $3 \mathrm{~h}$ when $5 \mathrm{mg}$ of enzyme protein of Phy2 was added to rapeseed cake, whereas $150 \mathrm{mg}$ of enzyme protein was necessary to achieve a similar result for Phy4. This means that the amount of Phy 4 must be 30 times higher than Phy2 to obtain the same effect, and therefore Phy4 may not be suitable for practical application. This leads to the recommendation that Phy2 is the most promising phytase used in the present in vitro experiment.

Use of exogenous phytase in dairy production is at present very limited. Our study indicates that exogenous phytase can enhance ruminal inositol phosphate degradation and thereby increase $\mathrm{P}$ availability and permit a lower allocation of $\mathrm{P}$ in the diet. However, it is not clear to what extent the observed inositol phosphate degradation in the present in vitro study reflects the in vivo situation, and further investigations regarding the effect of exogenous phytase allocated in vivo are needed.

\section{CONCLUSIONS}

The effect of adding exogenous phytase on inositol phosphate hydrolysis in feedstuffs in vitro depends on the type of feed, incubation time, concentration of phytase, and type of phytase. In non-heat-treated wheat, inositol phosphate was rapidly degraded in the control sample and no additional effect of phytase (Phy1) was observed in this case. Addition of each of the 4 experimental phytases used in the experiment increased degradation of inositol phosphates in rapeseed cake, but Phy2 and Phy4 were shown to be the most effective. However, much less enzyme protein of Phy2 was needed to obtain the same effect as achieved with Phy 4 and thus Phy2 appears most promising under rumen-like conditions.

\section{ACKNOWLEDGMENTS}

The authors gratefully acknowledge Inger Østergaard (Aarhus University, Tjele, Denmark) and Daisy Hilbrands (Novozymes A/S, Bagsvaerd, Denmark) for their skillful technical assistance. Funding for the present study was provided by the Danish Food Industry Agency (no. 3412-08-02257), Novozymes A/S (Bagsvaerd, Denmark) and Faculty of Agricultural Sciences, Aarhus University (Tjele, Denmark).

\section{REFERENCES}

Bravo, D., F. Meschy, C. Bogaert, and D. Sauvant. 2000. Ruminal phosphorus availability from several feedstuffs measured by the nylon bag technique. Reprod. Nutr. Dev. 40:149-162.

Carlsson, N. G., E. L. Bergman, E. Skoglund, K. Hasselblad, and A. S. Sandberg. 2001. Rapid analysis of inositol phosphates. J. Agric. Food Chem. 49:1695-1701.

Clark, W. D., J. E. Wohlt, R. L. Gilbreath, and P. K. Zajac. 1986. Phytate phosphorus intake and disappearance in the gastrointestinal tract of high producing dairy cows. J. Dairy Sci. 69:31513155 .

Dou, Z., J. D. Ferguson, J. Fiorini, J. D. Toth, S. M. Alexander, L. E. Chase, C. M. Ryan, K. F. Knowlton, R. A. Kohn, A. B. Peterson, J. T. Sims, and Z. Wu. 2003. Phosphorus feeding levels and critical control points on dairy farms. J. Dairy Sci. 86:3787-3795.

Eeckhout, W., and M. De Paepe. 1994. Total phosphorus, phytatephosphorus and phytase activity in plant feedstuffs. Anim. Feed Sci. Technol. 47:19-29.

Engelen, A. J., F. C. Van Der Heeft, P. H. G. Randsdorp, and E. L. C. Smit. 1994. Simple and rapid determination of phytase activity. J. AOAC Int. 77:760-764.

Frias, J., R. Doblado, J. R. Antezana, and C. Vidal-Valverde. 2003. Inositol phosphate degradation by action of phytase enzyme in legume seeds. Food Chem. 81:233-239. 
Irving, G. 1980. Phytase. Pages 85-98 in Inositol Phosphates. Their Chemistry, Biochemistry and Physiology. D. J. Cosgrove, ed. Elsevier Scientific Publishing Company, Amsterdam, the Netherlands.

Kincaid, R. L., D. K. Garikipati, T. D. Nennich, and J. H. Harrison. 2005. Effect of grain source and exogenous phytase on phosphorus digestibility in dairy cows. J. Dairy Sci. 88:2893-2902.

Knowlton, K. F., J. S. Radcliffe, C. L. Novak, and D. A. Emmerson. 2004. Animal management to reduce phosphorus losses to the environment. J. Anim. Sci. 82(E. Suppl.):E173-E195.

Knowlton, K. F., M. S. Taylor, S. R. Hill, C. Cobb, and K. F. Wilson. 2007. Manure nutrient excretion by lactating cows fed exogenous phytase and cellulase. J. Dairy Sci. 90:4356-4360.

Konishi, C., T. Matsui, W. Park, H. Yano, and F. Yano. 1999. Heat treatment of soybean meal and rapeseed meal suppresses rumen degradation of phytate phosphorus in sheep. Anim. Feed Sci. Technol. 80:115-122.

Morse, D., H. H. Head, and C. J. Wilcox. 1992b. Disappearance of phosphorus in phytate from concentrates in vitro and from rations fed to lactating dairy cows. J. Dairy Sci. 75:1979-1986.

Morse, D., H. H. Head, C. J. Wilcox, H. H. Van Horn, C. D. Hissem, and B. Harris Jr.. 1992a. Effects of concentration of dietary phosphorus on amount and route of excretion. J. Dairy Sci. 75:30393049.

Mullaney, E. J., and A. H. Ullah. 2003. The term phytase comprises several different classes of enzymes. Biochem. Biophys. Res. Commun. 312:179-184.

Nakashima, B. A., T. A. McAllister, R. Sharma, and L. B. Selinger. 2007. Diversity of phytases in the rumen. Microb. Ecol. 53:8288.

Nelson, T. S., L. B. Daniels, J. R. Hall, and L. G. Shields. 1976. Hydrolysis of natural phytate phosphorus in the digestive tract of calves. J. Anim. Sci. 42:1509-1512.

Nelson, T. S., L. W. Ferrara, and N. L. Storer. 1968. Phytate phosphorus content of feed ingredients derived from plants. Poult. Sci. 47:1372-1374.

Park, W. Y., T. Matsui, C. Konishi, S. Kim, F. Yano, and H. Yano. 1999. Formaldehyde treatment suppresses ruminal degradation of phytate in soybean meal and rapeseed meal. Br. J. Nutr. 81:467471.

Pontoppidan, K., D. Pettersson, and A. S. Sandberg. 2007. Peniophora lycii phytase is stabile and degrades phytate and solubilises minerals in vitro during simulation of gastrointestinal digestion in the pig. J. Sci. Food Agric. 87:2700-2708.

Poulsen, H. D., K. Blaabjerg, and D. Feuerstein. 2007. Comparison of different levels and sources of microbial phytases. Livest. Sci. 109:255-257.

Raun, A., E. Cheng, and W. Burroughs. 1956. Phytate phosphorus hydrolysis and availability to rumen microorganisms. J. Agric. Food Chem. 4:869-871.

Sehested, J., and P. Lund. 2007. Ruminal degradation of inositol bound $\mathrm{P}$ is affected by feed composition and external phytase. Page 328 in Book of Abstracts No. 13 (2007), 58th Annu. Mtg. Eur. Assoc. Anim. Prod., Dublin, Ireland. Wageningen Academic Publishers, Wageningen, the Netherlands.

Sharpley, A. N., and P. J. A. Winthers. 1994. The environmentallysound management of agricultural phosphorus. Fert. Res. 39:133146. (Abstr.)

Skoglund, E., N. G. Carlsson, and A. S. Sandberg. 1997. Determination of isomers of inositol mono- to hexaphosphates in selected foods and intestinal contentsusing high-performance ion chromatography. J. Agric. Food Chem. 45:431-436.

Tilley, J. M. A., and R. A. Terry. 1963. A two-stage technique for the in vitro digestion of forage crops. J. Br. Grassl. Soc. 18:104-111.

Viveros, A., C. Centeno, A. Brenes, R. Canales, and A. Lozano. 2000. Phytase and acid phosphatase activities in plant feedstuffs. J. Agric. Food Chem. 48:4009-4013.

Wodzinski, R. J., and A. H. J. Ullah. 1996. Phytase. Adv. Appl. Microbiol. 42:263-302.

Wu, Z., L. D. Satter, and R. Sojo. 2000. Milk production, reproductive performance, and fecal excretion of phosphorus by dairy cows fed three amounts of phosphorus. J. Dairy Sci. 83:1028-1041.

Yanke, L. J., H. D. Bae, L. B. Selinger, and K. J. Cheng. 1998. Phytase activity of anaerobic ruminal bacteria. Microbiology 144:15651573 . 